\title{
Financial Architecture and Economic Performance: International Evidence
}

\author{
By: Solomon Tadesse
}

William Davidson Working Paper Number 449

August 2001 


\title{
Financial Architecture and Economic Performance: International Evidence
}

\author{
Solomon Tadesse* \\ The University of South Carolina
}

Current Version

August 2001

JEL Classification: G1, G21, O1, 04

Keywords: Financial Systems, Banking, Economic Growth

\footnotetext{
* Moore School of Business, University of South Carolina, Columbia, SC 29208; Telephone: (803) 7774917; Fax: (803) 777-3609; E-mail: tadesse@sc.edu. I thank Raghu Rajan for insightful discussions and helpful comments. I benefited from the comments of seminar participants at the Symposium on Banking in Emerging Markets, University of Michigan and at the Asian Pacific Finance Association Conference, Bangkok, Thailand. I thank Thorsten Beck, Patrick Bolton, Florencio Lopez-de-Silanes, and Anjan Thakor for helpful comments. Funding from CIBER at University of South Carolina is gratefully acknowledged.
} 


\title{
Financial Architecture and Economic Performance: International Evidence
}

\begin{abstract}
The paper examines the relations between the architecture of an economy's financial system - its degree of market orientation - and economic performance in the real sector. We argue that the relative effectiveness of bank-based versus market-based financial systems depends on the strength of the contractual environment and the extent of agency problems in the economy. We find that while market-based systems outperform bankbased systems among countries with developed financial sectors, bank-based systems fare better among countries with underdeveloped financial sectors. Countries dominated by small firms grow faster in bank-based systems and those dominated by larger firms in market-based systems. The findings suggest that recent trends in financial development policies that indiscriminately prescribe market-oriented financial-system-architecture to emerging and transition economies might be misguided because suitable financial architecture, in and of itself, could be a source of value.
\end{abstract}




\section{Introduction}

An important long-standing issue in corporate finance has been the relative merits of banks and financial markets as providers of capital. A macro-economic version of this question is whether the financial architecture of an economy - i.e. the degree to which its financial system is bank-oriented or market-based - has any impact on economic performance in the real sector. Does a financial architecture anchored on markets work better than one centered on banks, and if so, under what conditions?

The theoretical literature is sparse in its predictions whereby lacking a unified approach, different theories emphasize specific features of banks and markets. Opinions range from the position that financial architecture has no real consequences to arguments emphasizing the inherent superiority of either market-based or bank-based systems. A middle ground position is to argue that the effectiveness of a particular architecture depends on a host of country specific factors. These may include the contractual environment of the country (e.g. Rajan and Zingales (1998b)), the informational structure of participating firms (e.g. Boot and Thakor (1997)), or the technological characteristics of the economy (Allen and Gale (1999b), Rajan and Zingales (1998b)).

In this paper, we use industry-level data from a panel of thirty-six countries to examine how a country's financial architecture affects performance in the real sector of the economy. We argue that the relative effectiveness of a given architecture depends on the level of development of the financial sector, the latter being a reflection of the supporting legal and institutional environment, and the prevalence and severity of agency problems in the economy. 
We find that financial architecture is not a matter of indifference in that real economic performance varies systematically across economies with differing financial system architecture. Across countries with underdeveloped financial sectors, industries from bank based economies grow faster than industries from market based systems, while industries in market-based systems grow faster across countries with developed financial systems. That is market-based financial systems significantly outperform bank-based systems across countries with developed financial sectors. Bank-based financial systems significantly outperform market-based systems across countries with underdeveloped financial sectors. Put differently, the degree of market orientation of the financial system is significantly positively related to economic performance in countries with developed financial sectors, whereas this relation is significantly negative in countries with underdeveloped financial sectors.

We also find that bank-based financial architecture outperforms market-based systems across countries dominated by small firms while market-based architecture fares well across countries populated with larger firms. Using the cross-country variation in the average firm size as a proxy for the variations in severity of agency problems, the finding appears to be consistent with the agency perspective to financial architecture that bank-based systems could be superior in situations of rampant moral hazard problem that needs close monitoring at which banks have a natural comparative advantage. This is also consistent with observations that, even in advanced countries, small firms rely on bank financing more so than on markets. Peterson and Rajan (1995) further document that, in the U.S., small firms secure better credit terms and access to capital in concentrated banking environment than in competitive banking. Nonetheless, Kumar, Rajan and Zingales(1999) report that financial development is key determinant of firm 
size across countries. Hence, given this partial endogeniety of firm size and financial development, it might be difficult to isolate the impacts of severity of agency problems from that of the strength of the contractual environment.

The findings indicate that financial architecture, in and of itself, could be a source of value. A lack of fit between the financial architecture, and the legal and institutional preconditions could retard economic performance. A market-oriented financial system does not fit well with an environment of weak contractability and lack of respect to the law. On the other hand, a synergic fit between the financial architecture and the contractual environment fosters economic growth.

The results suggest that the recent trend in policy-making circles of prescribing market-based systems indiscriminately across emerging and transition economies might be misguided. Markets require requisite institutional and legal infrastructure. In situations where strong contractual environment is lacking, as in many emerging and transition economies, there is more economic value in strengthening the banking sector. The key feature of relationship-based financial systems is the relative lack of competition and transparency, potentially causing inefficient investment and financing decisions as there would be a lack of external price signals to guide decisions. On the other hand, relationship-based finance has an important advantage of being flexible in accommodating firms with short-term difficulties that have otherwise long term prospect. Established relationships enable creditors to benefit from future successes, as well as 'dynamically cross-subsidize' younger, potentially profitable firms with short term financial difficulty from mature firms that have the ability to pay.

A growing literature underscores the importance of financial sector development to economic growth. Levine and Zervos(1998), Rajan and Zingales(1998a), and 
Demirguc-Kunt and Maksimovic (1998) explore the impact of financial development on economic growth at country, industry and firm levels respectively. While recognizing the importance of overall financial development, others stress the role of financial system design in impacting the mode of financing, governance and ultimately the performance of the real economy (see Allen (1999a) for an extensive discussion of this literature).

The paper is related to recent theoretical literature comparing bank-based financial system architecture with market based financial systems (Allen and Gale (1999a), Rajan and Zingales (1998b) and Boot and Thakor (1997)). Rajan and Zingales (1998b) emphasize the strength of the contractual environment as determinant of the effectiveness of market based versus bank based systems. Boot and Thakor (1997) underscores the importance of particular agency problems in the economy as dictating the relative merits of one architecture over another. They conjuncture that bank based systems add value to economies where post-lending moral hazard is a dominant problem. Allen and Gale (1998) emphasizes the value of information aggregation provided in market oriented systems for economies where decision environments are more complex as in industries with frequent technological change. Demirguc-Kunt and Levine (1999) provide evidence of relations between the legal environment and financial architecture. Common law countries and countries with strong protection of minority shareholders tend to have market-based systems

This paper examines the differential impacts of the market orientation of the financial system (i.e. financial architecture) across countries of different contractual environments. It also assesses the role of agency problems on the relative merits of the two architectures by exploring country characteristics, such as typical size of firms, as 
proxies for the severity of agency problems. In so doing, the paper sheds light on the ongoing debate on the relative merits of market-based versus relationship finance.

The paper is related to Levine (2000) and Beck and Levine (2000). In a crosscountry study, Levine (2000) examines the impact of financial architecture on economic performance, in particular on per capita GDP growth and its sources. Beck and Levine (2000) examine whether growth rates of industries that differ in external financial dependence depend on countries' financial architecture. Both Levine (2000) and Beck and Levine(2000) identify overall financial development and not financial system architecture as key determinant of growth. The main difference between our study and the two is our emphasis on differences in contractual environments across countries and differential degree and prevalence of agency problems to identify the comparative advantages of financial system architectures.

The balance of the paper is as follows. Section II presents the theoretical arguments on the merits of the two forms of financial architecture and develops testable hypotheses. Section III introduces the data and the empirical methodology. Section IV discusses the results and Section V concludes.

\section{Financial Architecture and Performance: Theory}

Markets as well as banks perform vital functions in an economy, which include capital formation, facilitation of risk sharing, information production and monitoring. The case for bank-based or market-oriented systems could be made based on the relative effectiveness with which banks or markets execute these common functions. The literature on the merits of banks versus markets is extensive and is outside the scope of 
this paper. At the extreme, some argue that market-based systems are inherently superior (see Macey (1998) and the recent literature on global convergence of corporate governance (e.g. Coffee (1999)) while others underscore the intrinsic value of banks (e.g. Gilson and Roe (1993)). By implication, adopting the superior financial architecture would enhance economic performance.

There are also middle-ground positions on the role of financial architecture. Some argue that financial architecture is inconsequential to the real sector with the belief that banks and markets are complementary in providing financial services, and that neither has a natural advantage in the provision of all services. Others argue that financial system architecture matters in that markets or banks may have a comparative advantage in delivering particular services depending on the economic and contractual environments of the country.

\section{A. Financial Architecture as a Matter of Indifference}

The indifference view which is partly based on the functional perspective to financial systems, stresses that a financial system provides bundles of services such as project evaluation, risk sharing, information production and monitoring. It is the quantity and quality of these services in an economy that matters, and not the venue by which they are provided (see Levine (2000) for an extensive review of this perspective). Hence, the market orientation of the financial system is of secondary importance, since both banks and markets provide both common and complementary services. This view has recently received more strength from the law and finance literature which stresses the importance of investor-protecting legal codes and their enforcement in enhancing financial services that promote economic performance (Laporta et al $(1997,1998,1999)$, see also Levine 
(2000)). La porta et al (1999) suggests that differences in depth and quality of financial systems as predicted by the quality of the supporting legal system is more important than distinctions in terms of bank or market orientation.

\section{B. Financial Architecture Relevance}

The perspective that holds that financial architecture matters rely on distinct differences in the types of services provided by markets and banks. A key attribute of financial markets - a feature that distinguishes them from banks - is that equilibrium prices formed in markets provide valuable information (about the prospect of investment opportunities) to real decisions of firms which, in turn, affect market prices. This is what is called the 'information feedback' function of markets. Tadesse (2000) provides empirical evidence that this market-based governance has a positive impact on economic performance. In particular, it has an effect of enhancing economic efficiency.

The relative importance of a given financial architecture (market vs banks) depends on the value of this market information (demand side argument) and how effectively markets perform this information aggregation function (supply side argument).

On the supply side, the relative merits of markets versus banks depend on the effectiveness with which markets can perform their information feedback function. Well functioning markets rely on contracts and their legal enforceability. Impediments to markets such as weak contractability reduce the supply of information aggregation as a market function. In this situation, a bank-based architecture, which survives in weak contractual environments, could be of superior value. Rajan and Zingales (1998b) postulates that the relative merits of the financial architectures are a function of the 
contractability of the environment and the relative value of price signals. Bank based systems naturally fits in situations with low contractability combined with high capital scarcity relative to investment opportunity. Market -based systems work better in situations of high contractability and high capital availability relative to investment opportunities (implying high value of price signals)

On the demand side, one would expect a revival of market-based systems in situations where information aggregation is especially valued. However, market generated information is not always considered useful for various reasons. First, not all decision environments benefit from price signaling. Allen (1993) and Allen and Gale (1999b) argue that the information feedback from markets would be most valuable in decision environments, such as new industries, in which consensus are hard to achieve about the optimal managerial rule due to rapid technological change, and constantly changing market conditions. Conversely, the value of information aggregation is lower in economies that are dominated by firms with less complex decision environments.

Second, the prevalence and severity of moral hazard attenuates the value of information feedback by financial markets. Boot and Thakor (1997) argue that banks provide a superior resolution of post-lending moral hazard resulting from potential distortions in firms' investment choices while markets provide improvements in real decisions through the information aggregation. However, the greater the moral hazard problem, the lower is information acquisition in the financial markets, and the smaller the value of market information in affecting real decisions. The value of market information is, therefore, lower in economies dominated by firms that are prone to moral hazard problems (e.g. poor credit reputations). This implies that, other things constant, a bank- 
based system might fit better to economies dominated by firms prone to more agency problems.

Third, the value of price signals also depends on the ease with which project selection could be accomplished in its absence. The value of price discovery is higher in situations where real decisions could be least likely distorted if not based on external information. Rajan and Zingles (1998b) points that in situations of extreme capital scarcity relative to available investment opportunities, real decisions, even in the absence of market information, are less likely to go wrong because, in this case, it would be relatively clear as to which investment would be profitable. Hence, all other things constant, the more capital abundance relative to investment opportunities in an economy, the higher is the value of information aggregation, and the more desirable a market-based architecture; and vice versa.

The foregoing implies that the real consequences of financial architecture (market-based vs bank-based) should depend on a host of country specific factors including the contractual environment of the economy, the associated severity of agency problems, and the degree of complexity of the decision environment in the economy. In the sections that follow, we examine empirically the real consequences of financial architecture across economies of differing contractual environments and differing prevalence of agency problems. We expect market-based architectures to perform better in countries with stronger contractual environment, and bank-based systems to fare well in contractually weak economies. This is what we call the contractual view to financial architecture. We expect bank-based systems to perform better in economies with firms that are observationally more prone to agency problems; and market based systems to 
fare better in countries with firms that are less susceptible to these problems. This is the agency view to financial architecture.

\section{Data and Methodology}

Our database combines international data on financial architecture and on financial development, industry level data on economic performance, and various measures of the legal and institutional environments of countries. We have complete data on these sets of variables for thirty-six countries. We have data on financial architecture and financial development for a large cross-section of countries, but industry performance data only for a matching 36 countries, thus limiting the size of our sample.

\section{A. Financial Architecture}

There is a lack of uniformly accepted empirical definition of whether a given country's financial system is market-based or bank-based. Previous studies use stylized facts based on a handful of countries, such as Germany as representation of bank-based system and the U.S. as a prototype of market-based system. We use a variety of financial architecture indicators based on aggregate cross-country data recently compiled at the World Bank. The data set described in Beck, Demirguc-Kunt, and Levine (1999) contains measures of the relative size, activity, and efficiency of the banking and market sub-sectors of the financial system for a broad cross-section of countries over the period 1980 to 1995 which also coincides with the period for which we have data on economic performance. For this study, we use two measures of financial architecture as described in Demirguc-Kunt and Levine (1999): ARCHITECTURE, a continuous variable, and 
MARKET, a dummy variable that distinguishes market-based countries from bank-based systems. The definitions of these variables as described in Demirguc-Kunt and Levine(1999) are as follows:

Architecture: Architecture is an index of the degree of stock market orientation of a financial system and is based on three indices of financial architecture based on measures of relative size, activity and efficiency of the stock market in a given country vis a vis those of the banking sector. Higher values of this index indicate a more marketOriented financial system. The variable ARCHITECTURE reflects the means-removed averages of three variables: architecture-size, architecture-activity and architectureefficiency.

Architecture-Size: Architecture- Size measures the relative size of stock markets to that of banks in the financial system. The size of domestic stock market is measured by market capitalization of domestic stocks to GDP ratio. The size of the banking sector is measured by the bank credit ratio defined as the claims of the banking sector against the private sector as a percentage of GDP. This excludes claims of non-bank intermediaries, and credit to the public sector. Architecture-Size combines the two size measures as a ratio of the capitalization ratio to bank credit ratio. Larger values indicate more market orientation.

Architecture-Activity: measures the activity of stock markets relative to that of banks, and is denoted by the ratio of total value of stocks traded to bank credit ratio. Total value traded as a share of GDP measures stock market activity relative to economic activity, and bank credit ratio (defined above) also indicate the importance of banks in the economic activities of the private sector. 
Architecture-Efficiency: measures the relative efficiency of a country's stock markets vis a vis that of its banks. Efficiency of stock markets is measured by the total value traded ratio defined to be the share of total value of shares traded to GDP. Efficiency of banking is measured by overhead costs defined to be the ratio of banking overhead costs to banking assets. Architecture-Efficiency is the product of total value traded ratio and overhead costs. Demirguc-Kunt, and Levine (1999) also present measures using turnover ratio (instead of value traded) and find no different rankings.

ARCHITECTURE, the conglomerate measure, takes, after removing the means of each series, the average of capitalization to bank credit ratio, value traded to bank credit ratio, and the product of value traded and overhead costs. For robustness, we also develop an alternative aggregation of the architecture variables. We generate a conglomerate measure as a principal component of the three architecture variables.

Market: MARKET, our alternative measure, is a dummy variable and classifies countries as market-based if they fall above the mean of the ARCHITECTURE, the conglomerate index, and as bank- based if they score below the mean of the index.

Table 1 presents country classifications based on financial architecture and financial development (discussed below). The top two panels list countries with marketbased financial architecture and the bottom two provide a list of bank-based systems. The average of the ARCHITECTURE variable for the market-based countries is 0.866 and that for bank based countries is -0.38141 . The difference is statistically significant at 1 percent. This is true comparing market-based economies and bank-based economies across underdeveloped countries (0.5300 against -0.40889$)$, as well as across developed economies (1.09 against -0.3608$)$. 


\section{B. Financial Development}

To control for the overall development of the financial systems, we classify countries into financially developed and financially underdeveloped based on two indices. Following Demirguc-Kunt and Levine (1999), we define a country as having underdeveloped financial system if it scores below the mean on both bank development and stock market development. Specifically, an underdeveloped financial system will have (1) lower than the mean for Bank-Credit ratio, and (2) lower than the mean for value traded ratio (i.e. value traded to GDP ratio).

We use this classification as a proxy for the differing contractual environment across groups of countries. La porta et al (1997) reports that capital market development is primarily dictated by legal protection and accompanying enforcement afforded by the countries' legal system. Specifically, countries with strong contractual environment, as reflected in the breadth of investor protecting legal provisions and strong enforcement of the laws, tend to have well developed securities markets. We use, therefore, the financial development classification as a proxy for differences in contractual environments.

Table 1 provides the classification of countries by financial development.

Countries on the left two panels are countries with under-developed financial sectors, and those on the right two panels are countries with developed financial systems. In this classification, Denmark is considered financially underdeveloped because it registers below the average on bank development and stock market development ${ }^{1}$. Measures of bank and stock market development are significantly higher in financially developed countries than in underdeveloped countries. The average bank ratio for developed

\footnotetext{
${ }^{1}$ The forgoing analysis is robust to classifying Denmark as financially developed or removing it altogether.
} 
countries is 0.728 versus 0.255 for underdeveloped countries; stock value traded to GDP ratio is 0.327 in developed countries versus 0.072 in underdeveloped countries.

\section{Economic Performance}

We use industry level data obtained from the United Nations Industrial Database to construct economic performance measures. The database contains data on the production and cost structure of manufacturing industries for the sample of countries. We use data on ten representative manufacturing industries. The economic performance measures include annual growth in industry real value added, growth in productivity and growth in production and economic efficiency. Real value-added is gross output less intermediate inputs, all stated in real terms.

Growth in value added could be a result of growth in factors of production and improvements in productivity. Productivity improvements, in turn, can be decomposed into growth in the efficiency with which resources are utilized given the technology of the firm, and technological change which reflects improvements in the products and processes. Efficiency improvements are measured in reference to cross country production (and cost) functions as representations of the best practice technology. Production efficiency is a measure of how closer an industry becomes to the best practice production frontier in its production structure. Economic efficiency is how closer an industry gets to the best-practice cost frontier in its cost structure. These measures are obtained from Tadesse (2000) which presents details on their construction.

Table 1 provides a summary of these performance measures for each country in the sample and summaries for the sub-sample of countries. Table 2 provides a simple comparison of performance between market-based and bank-based systems without 
making distinction based on contractual environment or firm size. For the full sample, there is no discernable difference in economic performance (for any of the performance measures) between bank-based countries and market-based economies. The same is true between financially developed countries and financially underdeveloped countries (see Table 2). Notice in Table 1, however, the differences in economic performance between market-based (top two panels) and bank-based economies (bottom two panels) for the developed (right two panels) and underdeveloped (left two panels) sub sample respectively. On each performance measure, the average economic performance of bankbased countries is significantly higher than that of market based countries in financially underdeveloped sub-sample. For example, growth in value added (0.0665 against 0.009), growth in production efficiency $(0.002$ versus -0.0006$)$ and growth in economic efficiency $(-0.007$ versus -0.1597$)$. The reverse is true (i.e. economic performance is better in market-based economies than in bank-based economies) among the countries that have developed financial systems.

\section{Results}

\section{A. Financial Architecture, Contractual Environment and Economic Performance}

As a preliminary step to gauge the relations between financial architecture and performance, we begin with a difference in means tests of economic performance between market-based systems and bank based systems. Table 3 groups countries into those with underdeveloped and those with developed financial systems. Within each group, we then compare economic performance measures between countries of marketbased architecture and those with bank-based systems. 
Across countries with developed financial systems, economic performance is significantly larger in countries with market-based financial architecture than in those with bank-based architecture. Conversely, across countries with underdeveloped financial systems, economic performance is significantly larger in countries with bankbased systems than in those with market-based architecture. This is true nearly for all measures of economic performance. For example, the average realized real growth rate in value added for market-based, financially well developed countries, $3.7 \%$, is statistically larger than that for bank-based financially well-developed countries $(0.8 \%)$. On the other hand, growth rate in value added for bank-based, financially underdeveloped countries, $6.3 \%$, statistically dominates that for bank-based, financially underdeveloped countries, $0.5 \%$. Across developed financial systems, the average growth rate in production efficiency for market-based economies (0.0008) is significantly larger than that for bank-based economies (-0.0004). For financially developed countries, the average growth rate in production efficiency for bank-based economies $(0.002)$ is significantly larger than that for market-based economies (-0.0008).

These preliminary results are consistent with the view that the effectiveness of a given financial architecture depends on the contractual environment of the economy. To further explore the patterns of relations that are emerging in the data, while controlling for potential country and industry heterogeneity that may derive the preliminary findings, we estimate an empirical model in which we attempt to explain cross country variation in growth in real value added based on variations in financial architecture. We begin with a regression model in which we include country and industry characteristics explicitly to control for these potential country and industry heterogeneity. Among the country characteristics, we include initial per capita GDP to control for the well-known 
convergence effect. As an industry characteristic, we include the output share of an industry to the total manufacturing output of the country to control for the relative importance of the industry in the country.

In addition, we estimate a random-effects specification of the following form where, besides the explicit controls, the latent country-related and industry-related sources of variations on growth are effectively accounted for:

$$
\begin{aligned}
& G_{c i}=\alpha+\beta F A_{c}+\sum_{c i} \gamma Z_{c i}+\phi F D_{c}+\delta\left(F A_{c} * F D_{c}\right)+\varepsilon_{c i} \\
& \text { where, } \\
& \varepsilon_{c i}=\lambda_{c}+\eta_{i}+e_{c i}
\end{aligned}
$$

The model is a three-way error component specification with random country and industry effects to explicitly account for the cross-correlation between error terms for observations in the same country and the same industry respectively. $F A$ is either of the financial architecture variables: ARCHITECTURE, the conglomerate measure of the market-orientation of the financial system, or MARKET, the dummy variable that takes 1 if the financial system is classified as market-oriented and 0 if not. FD is indicator of financial development in a given country. Specifically, we use the dummy variable UNDER, which takes the value 1 for financially underdeveloped systems to indicate financial development. $Z$ represents a host of explicit control variables. In all the specifications, we include initial per capita GDP of countries to control for the impact of initial conditions on economic growth. We also include the output share of an industry to the total manufacturing output of the country. $\lambda$, and $\eta$, are random country and industry effects intended to capture the latent country-related and industry-related sources of 
variations on growth. The dependent variable, $\mathrm{G}$, is the average annual growth rate in value added of industry i, in country c over the period 1980 through 1995. (Summary statistics for the variables is provided in Appendix I). We expect a positive relation between growth and financial architecture in financially developed economies and negative in financially underdeveloped ones.

Table 4 presents the results of regressions across 10 industries in 36 countries around the world. We use the dummy variable UNDER, which takes the value 1 for financially underdeveloped systems to indicate financial development. This variable represents a proxy for the strength of the underlying contractual environment. For measuring financial systems architecture, we use the dummy variable MARKET which takes 1 for market-based systems and, alternatively, the continuous variable ARCHITECTURE. The focal variables for testing the hypotheses are the interaction variables: UNDER X MARKET and UNDER X ARCHITECTURE.

From the OLS regressions, in column I, the coefficient on the interaction between UNDER and MARKET is negative and statistically significant, implying that, other things equal, market orientation of the financial system is inversely related to growth in real output in financially underdeveloped and hence contractually weak countries. The MARKET variable enters with positive sign, implying a positive relation between market orientation and growth in financially developed countries, though this relation is somehow weaker than for financially underdeveloped countries. Column II reports similar results based on the continuous variable ARCHITECTURE. The coefficient on the variable ARCHITECTURE is positive and highly statistically significant, implying that, among countries that are financially developed, market orientation of a financial 
system is positively associated with growth. The interaction variable between ARCHITECTURE and UNDER is negative and statistically significant at $1 \%$ significance level. The absolute value of this coefficient (0.046) is very large in magnitude compared to the coefficient for ARCHITECTURE (0.017). This implies that, other things equal, across countries that are financially underdeveloped, relatively market-based systems tend to achieve lower output growth.

As would be expected, per Capita GDP has significant negative coefficients. Poorer countries grow faster, other things equal. The magnitude of the implied rate of convergence is comparable to what is found in the growth literature. Industry effects appear to be less important as the industry's share in total manufacturing output has no relationship with industry growth.

The random-effects specification provides similar results. In column I, the interaction between UNDER and MARKET is negative and statistically significant, implying that, other things equal, across countries that are financially underdeveloped and hence with weaker contractual environments, industries grow faster in those countries with bank-based financial systems. In column II, the coefficient for ARCHITECTURE is positive and significant, indicating that in financially developed countries, market orientation is positively related to industry growth. This result is relatively weak. On the other hand, the interaction term is negative and significant. The magnitude of this coefficient is larger than the coefficient on ARCHITECTURE. Financial architecture, the relative market orientation of financial system, is inversely related to industry growth in financially underdeveloped economies. Increasing marketorientation slows growth in financially underdeveloped and hence contractually weak 
countries; yet it increases growth in financially developed and contractually strong countries. For example, a one standard deviation (0.654) increase in ARCHITECTURE slows industry growth by an average rate of $1.7 \%$ in financially underdeveloped economies while the same change in the variable increases industry growth in value added by about $1.2 \%$ in financially developed, and hence contractually strong countries. Markets and banks provide vital financial services. A growing literature documents the positive impact of these services on economic performance. Levine and Zervos (1998) find that both bank development (measured by bank ratio) and stock market development (particularly in terms of market liquidity) positively impacts growth in per capita GDP. Tadesse (2000) finds that stock market liquidity has a positive impact on measures of efficiency, productivity and growth in value added.

For robustness, we would like to gauge the marginal impact of financial systems architecture, controlling for the effects of financial development. Columns III and IV of Table 4 present the results of regressions in which we include market turnover ratio and bank credit ratio to control for capital market functions. As would be expected, both turnover and bank ratio have positive and significant impacts on industry growth. The variables have the same order of magnitude as found in the literature. More importantly, the impacts of financial architecture on growth are the same after controlling for turnover and bank-ratio. From the random-effects estimations, the interaction of Market and Under (column III) and the interaction of Architecture and Under (column IV) are significantly negative, indicating inverse relations between market orientation and industry growth. 
The evidence underscores bank-based systems as superior venues for financially underdeveloped economies and market-based systems as fitting financially developed economies. The finding is consistent with Rajan and Zingales (1998b)'s conjuncture that market-based systems prosper in situations of strong contractual environment and bankbased systems where such is lacking. The level of financial development of countries reflects the degree of contractability of the environment. In an environment where the legal and institutional infrastructure is poor and hence lacks contract enforceability, investors rely on hierarchies and relationships as powers to prevent expropriation (solution to corporate governance), implying that institutions would be more effective and fitting than markets. One would therefore expect bank-based (relationship based) systems to perform well in financially underdeveloped environments.

\section{B. Financial Architecture, Firm Size and Economic Performance}

The agency perspective to financial architecture as advanced in Boot and Thakor (1997) suggests that the relative merits of the bank-based and market based financial architectures depend on the informational environment of the economy. Noting the comparative advantages of banks in monitoring post-lending moral hazard, and of markets in aggregating information for real decisions, they conjecture that bank based systems would fare better in economies where hidden action (moral hazard) problems predominate. The greater the agency problem in the economy, the less incentive investors have to acquire information in the financial markets. As a result, the lower is the usefulness of market information in affecting real decisions, while the more valuable is bank monitoring in mitigating the prevalent moral hazard. This implies that, other 
things constant, a bank-based system might fit better to economies dominated by firms observationally more prone to agency problems.

A gross indicator of the severity of agency problems across countries might be the dominance of small versus large firms in the given country. While agency problems prevail across firm types, it can be argued that moral hazard is more severe among lessreputed and less-transparent small firms. One can then classify countries by the average size of a typical firm as indicator of whether a country is populated by less reputed small firms implying heightened problem of moral hazard.

Table 5 presents a difference in means test of economic performance for countries classified by the size of the average (or typical) firm in the manufacturing sector. We have data on the total number of firms and total real gross output in the manufacturing sector of each country. Size of the average firm is calculated as total manufacturingsector gross output divided by total number of firms in the manufacturing sector. The ( $\log$ of) size of the average firm ranges from 7.68 in Jordan to 12.352 in Germany. The size distribution appears to correlate with the level of development of countries. Dividing the sample into two, small firm countries generally include emerging economies such as Sri Lanka, India, Indonesia, Jordan, Peru and others; and large firm countries include such developed economies as Germany, Finland, Austria, Canada, the U.S and others.

We categorize countries into quartiles by the size of the typical firm in each country. Table 5 presents a comparison between countries in the bottom quartile and in the top quartile. The results indicate that market based systems outperform bank based systems in economies dominated by large firms (i.e. the top quartile) and that bank-based systems outperform market based systems in countries dominated by small firms (i.e. 
bottom quartile). The differences between the means of the corresponding performance measures are statistically significant. Across countries that are the lowest quartile in firm-size, industries in bank-based systems register annual growth rate in value added of $6.5 \%$ while those in market-based systems register a rate of $-4.6 \%$. In countries with the top firm-size quartile, those industries in market-base economies achieve annual growth rate of 3\% while their counterparts in bank-based systems register a $0.8 \%$. These preliminary results appear to support the agency perspective on financial architecture that market based systems might be valuable where information aggregation is important and bank based systems are valuable in conditions where ex post moral hazard is an important problem.

Table 6 presents results of growth regressions where firm-size classification is a variable. SIZE is a dummy variable that takes 1 if a country scores in the lower third in average manufacturing firm size ranking and 0 if it ranks in the top third. MARKET is a dummy variable that takes 1 for market-based financial systems and 0 otherwise.

ARCHITECTURE is a continuous variable denoting the relative market orientation of the financial system. The focal variables of interest are the interaction between financial architecture and firm-size: MARKET X SIZE and ARCHITECTURE X SIZE. We expect the coefficients of the interaction terms to be significantly negative.

Column I and column II report the results using the MARKET variable and the ARCHITECTURE variables respectively. From the OLS results, the coefficient on the size variable is negative and significant, implying that countries dominated by smaller firms tend to grow slower. The coefficient on the interaction term is negative and statistically significant at $1 \%$. The interpretation is that in countries that are dominated 
by smaller firms, market-based financial systems retard growth (inversely bank-based systems promote growth). This is also true in column II where we use the continuous ARCHITECTURE variable. The interaction term is significantly negative implying that market-orientation is inversely related to growth in countries dominated by smaller firms. In column II, furthermore, the coefficient on SIZE is negative and significant, indicating that, other things constant, countries with small firms grow slower on average. Similar results obtain in the random-effects specification. In column I, the interaction MARKET $\mathrm{X}$ SIZE is negative and highly significant, indicating that market-based systems retard growth in countries dominated by smaller firms. The size variable has a negative coefficient, but is statistically not significant; hence, other things equal, being a country with predominantly small firms or predominantly large firms has no impact on growth. In column II, the interaction term has a significant negative coefficient, again indicating an inverse relation between market orientation and industry growth in countries with smaller firms. Columns III and IV report results controlling for market turnover ratio and bank ratio as proxies for capital market functions. The evidence that marketorientation adversely impacts industry growth in countries with small firms is robust both in the OLS and random-effects specifications. The coefficients of the interaction terms are significantly negative.

To the extent that firm-size proxies for differences in the extent of agency problems, the results are consistent with the agency perspective to financial architecture in which bank-based systems are assumed to be fitting to economies with severe agency problems that require monitoring in which banks excel (Boot and Thakor (1997)). In countries populated by smaller firms, where investment distortions due to moral hazard 
tend to be endemic problem, bank monitoring becomes especially useful. Moreover, in those circumstances where serious investment distortions prevail, investors lack the incentive to collect market information, rendering the comparative advantage of markets - i.e. market feedback (or information aggregation) function- ineffective.

It should be noted, however, that it is difficult to empirically distinguish this agency perspective from the contractual view in which the effectiveness of a given architecture is assumed to depend on the strength of the contractual environment. There is a partial endogeneity between firm size and financial development. Kumar, Rajan and Zingales(1999) report that the strength of contractual environment is one of the key determinants of firm size. In our sample, the size classification and the financial development classification have a correlation of 0.467 . Hence, an alternative interpretation of the evidence on firm size could be as a confirmation of the contractual view that the relative effectiveness of a financial architecture depends on the strength of the underlying contractual environment. For example, the evidence that countries with small firms fare better in bank-based architecture might suggest that bank-based systems complement weak contractual environment because low financial development, among others, tend to foster smaller firm size.

\section{Robustness}

In this subsection, we briefly describe the results of some of the robustness checks of our findings. One major concern is the difficulty of classifying countries as marketbased or bank-oriented and whether the results are shaped by the particular classification scheme adopted in the paper. In the analysis, we classified countries based on the 
means-removed average of the size, activity and efficiency measures of countries' financial architecture. For robustness, we generated a different ranking of countries based on the principal components of the size, activity and efficiency of financial architecture. Levine (2000) uses this scheme. In the new classification, Chile and Denmark qualify as market-based; and Belgium, Israel, and Jordan become bank-based. Furthermore, the continuous variable (ARCHITECTURE) takes new values. We repeat the analysis using these new variables, and apply the random-effects version of our model. The results are robust both in direction and magnitude. In Table 7, in columns I, the interaction term between the architecture variable MARKET and UNDER is significantly negative and of the same order of magnitude. Market-oriented financial systems retard growth (or conversely, bank-oriented systems promote growth) in financially underdeveloped economies. The same is true in Column II where the interaction term between the continuous architecture variable - ARCHITECTURE - and the financial development variable - UNDER - is found to be significantly negative. Column III and IV report results on the impact of firm size using the new measures of financial architecture. The coefficients of the interaction terms between SIZE and the financial architecture variables are negative and statistically significant, implying that market-oriented systems retard growth (and conversely, bank-oriented systems promote growth) in countries dominated by smaller firms.

In the original regressions where we classify countries by typical firm size, we categorize countries into 3 size categories, and we compare the top and bottom third as large firm and small firm countries respectively. This classification results in the U.K. and Japan in the middle category. We include the two countries in the large category to 
check for the sensitivity of the findings. The results are in column VI and V. The interaction variables are negative, statistically significant and are of similar magnitude. To further check the sensitivity of the results to changes in the size classification scheme, we categorize the countries into size quartiles and compare the bottom and top quartiles as small versus large firm countries. The results are not sensitive to such changes as can be seen under column VI and VII. The coefficients are significant and are of comparable magnitude. The findings that bank-based systems promote growth in countries of relatively small firms appear to be robust to variations in country classifications into size groupings as well to how we classify countries into bank based or market based financial architectures.

\section{Conclusion}

Countries differ in the way their financial sector is configured, ranging from the market-based systems typical of the Anglo-Saxon traditions to bank-centered systems characteristic of Continental Europe and Japan. An important issue in corporate finance is the question of whether this diversity in financial system architecture has any consequence to economic performance in the real sector. Does a financial architecture anchored on markets work better than one centered on banks, and if so, under what conditions?

Based on industry-level data from a panel of thirty-six countries, the paper examines how a country's financial architecture affects performance in the real sector of the economy. We argue that the relative effectiveness of a given architecture depends on 
the level of development of the financial sector, the latter being a reflection of the supporting legal and institutional environment, and the prevalence and severity of agency problems in the economy.

We find that financial architecture is not a matter of indifference in that real economic performance varies systematically across economies with differing financial system architecture. Across countries with developed financial sectors, industries supported by market-based financial systems grow faster than industries with bank-based systems. Conversely, bank-based financial systems significantly outperform marketbased systems across countries with underdeveloped financial sectors. Furthermore, we find that market-oriented systems retard economic growth and conversely, bank-oriented systems promote growth in countries dominated by smaller firms.

The evidence suggests that financial architecture, in and of itself, could be a source of value. A lack of fit between the legal and institutional preconditions, and the financial architecture retards economic performance. A market-oriented financial system does not fit well with an environment of weak contractability and lack of respect to the law. On the other hand, a synergic fit between the financial architecture and the contractual environment fosters economic growth. In view of the evidence, recent directions in capital-market-development policy that prescribe market-oriented financial systems indiscriminately, particularly in emerging and transition economies might be misguided. It suggests that in situations where the requisite legal and institutional preconditions are lacking, economies fare much better through strengthening their banking sector instead. 


\section{References}

Allen, F., 1993. Stock markets and resource allocation. In C. Mayer and X. Vives (eds.), Capital Markets and Financial Intermediation. Cambridge: Cambridge University Press.

Allen, F., D. Gale, 1999a. Comparing Financial Systems. Cambridge, MA: MIT Press.

Allen, F., D. Gale, 1999b. Diversity of Opinion and the Financing of New Technologies. Journal of Financial Intermediation, 8: 68-89.

Beck, T., A. Demirguc-Kunt, R. Levine, 1999. A new database on financial development and structure. Washington, D.C: World Bank, mimeo.

Beck, T. and R. Levine, 2000. External dependence and industry growth: does financial structure matter? World bank working paper.

Boot, A., A.V. Thakor, 1997. Financial systems architecture. Review of Financial Studies, 10, 693-733.

Coffee, C. J, 1999. The future as history: The Prospect for global convergence in corporate governance and its implications. Columbia University Working paper.

Demirguc-Kunt, A., R. Levine, 1999. Bank-based and market-based financial systems: cross-country comparisons, Washington D.C.: World Bank, mimeo.

Demirguc-Kunt, A., V. Maksimovic, 1998. Law, Finance, and Firm Growth. Journal of finance. 53:2107-37.

Gilson, R., M. Roe, 1993. Understanding the Japanese Keiretsu: Overlaps between corporate governance and industrial organization. Yale Law Journal, 102.

Kumar, K., B., R. G. Rajan, L. Zingales, 1999, What Determines Firm Size? Cambridge, MA: NBER, mimeo.

Laporta, R, F. Lopez-de-Silanes, A. Shleifer, R.W. Vishney, 1999. The quality of government. Journal of law, economics and organization. 15:222-79.

Laporta, R, F. Lopez-de-Silanes, A. Shleifer, R.W. Vishney, 1998. Law and finance. Journal of Political Economy. 106: 1113-55.

Laporta, R, F. Lopez-de-Silanes, A. Shleifer, R.W. Vishney, 1997. Legal determinants of external finance. Journal of finance. 52:1131-50. 
Levine, R., 2000. Bank-based or market-based financial systems: which is better? World Bank working paper.

Levine, R., S. Zervos, 1998. Stock Markets, Banks, and Economic Growth. American Economic Review.

Macey, Jonathan, 1998. Measuring the effectiveness of different corporate governance systems: toward a more scientific approach. Journal of Applied Corporate Finance.

Petersen, M. and R. Rajan, 1995. "The Effect of Credit Market Competition on Lending Relationships,” Quarterly Journal of Economics, 110: 407-443.

Rajan, R., L. Zingales, 1998b. Which Capitalism? Lessons from the East Asian Crisis. Journal of Applied Corporate Finance.

Rajan, R., L. Zingales, 1998a. Financial dependence and growth. American Economic Review.

Tadesse, S., 2000. The Information and Monitoring Role of Capital Markets: Theory and International Evidence. University of South Carolina, Working Paper. 


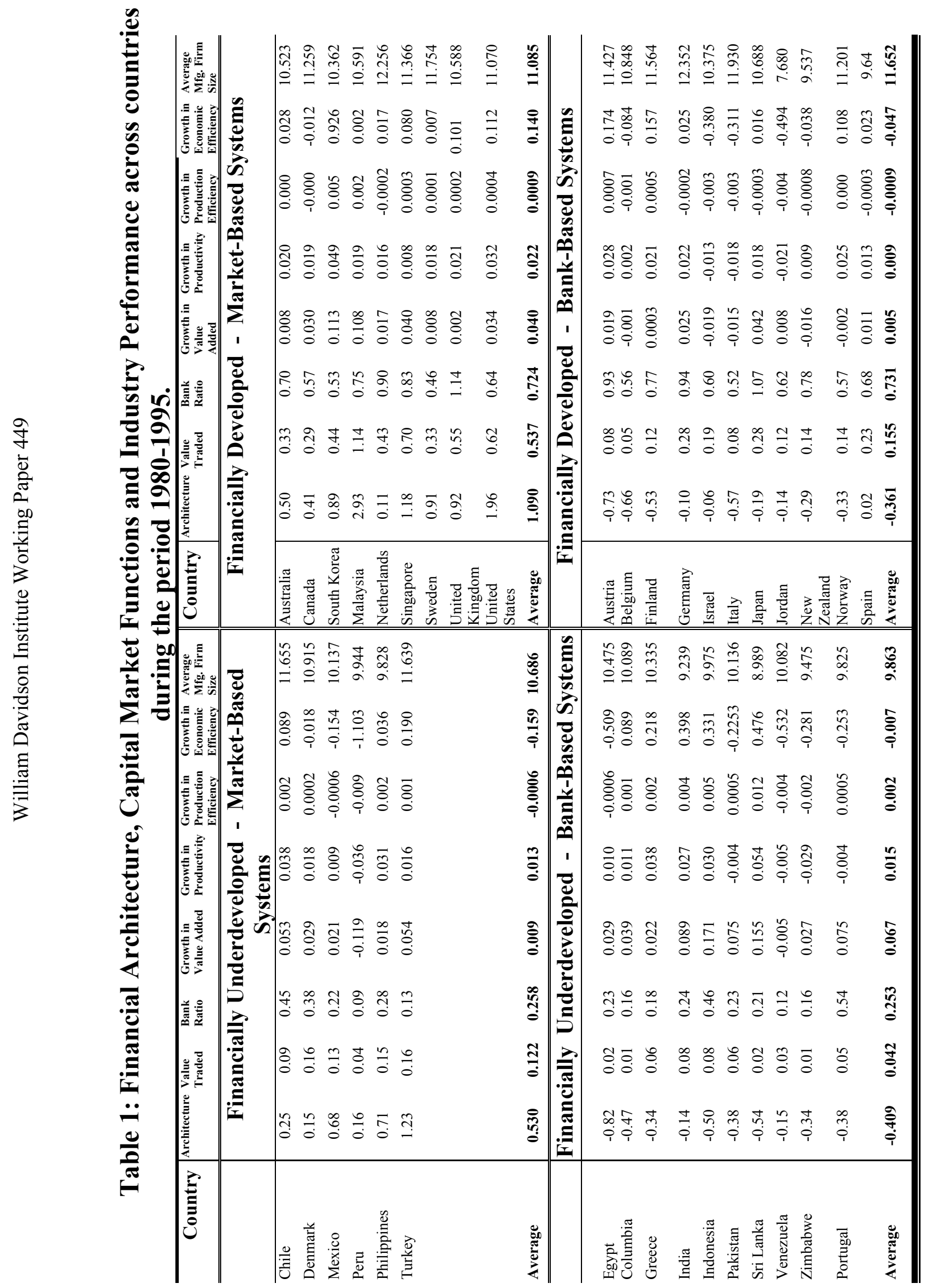




\section{Table 2: Financial Architecture and Economic Performance}

Industry growth in real value added is the average annual compounded growth rate in real value added for each of the ten industries in each of the thirty-six countries over the period 1980 to 1995. Productivity and efficiency are computed based on parameter estimates of cross-country stochastic production and cost frontiers on the panel of industry production and cost data. Production efficiency measures the degree to which an industry diverges from the efficient production frontier. Economic efficiency measures the degree to which an industry diverges from the best practice cost frontier. Financial Architecture is a continuous variable that measures the degree of market orientation of a financial system and is an average of the means-removed values of size, activity and efficiency measures. Market based dummy is a variable that takes 1 if the financial system is classified as market-based and 0 if it is bank-based. Developed financial systems are countries with above average stock market liquidity and the ratio of bank credit to private sector to GDP.

\begin{tabular}{|l|c|c|c|c|}
\hline & $\begin{array}{c}\text { Growth in Value } \\
\text { Added }\end{array}$ & $\begin{array}{c}\text { Growth in } \\
\text { Production } \\
\text { Efficiency }\end{array}$ & $\begin{array}{c}\text { Growth in } \\
\text { Economic } \\
\text { Efficiency }\end{array}$ & $\begin{array}{c}\text { Growth in } \\
\text { Productivity }\end{array}$ \\
\hline Financial Structure & 0.037 & 0.001 & 0.0005 & 0.016 \\
Bottom 25\% & 0.039 & 0.001 & 0.0013 & 0.023 \\
T-test & -0.16 & 0.12 & -0.46 & -0.69 \\
\hline Bank vs Market & 0.030 & 0.0004 & 0.0001 & 0.014 \\
Bank Based & 0.023 & 0.0001 & -0.0001 & 0.018 \\
Market Based & 0.98 & 0.61 & 0.19 & -0.73 \\
T-test & & & & \\
\hline $\begin{array}{l}\text { Financial System } \\
\text { Development }\end{array}$ & 0.037 & 0.0005 & -0.0009 & 0.013 \\
Developed & 0.020 & 0.0001 & 0.0007 & 0.017 \\
Underdeveloped & $2.23^{\mathbf{b}}$ & 0.59 & -1.23 & -0.52 \\
T-test & & & & \\
\hline
\end{tabular}

${ }^{a}$ Significant at $1 \% ;{ }^{b}$ Significant at $5 \% ;{ }^{c}$ Significant at $10 \%$ 


\section{Table 3: Financial Architecture and Economic Performance: Summary}

Industry growth in real value added is the average annual compounded growth rate in real value added for each of the ten industries in each of the thirty-six countries over the period 1980 to 1995 . Productivity and efficiency are computed based on parameter estimates of cross-country stochastic production and cost frontiers on the panel of industry production and cost data. Production efficiency measures the degree to which an industry diverges from the efficient production frontier. Economic efficiency measures the degree to which an industry diverges from the best practice cost frontier. Financial Architecture is a continuous variable that measures the degree of market orientation of a financial system and is an average of the means-removed values of size, activity efficiency measures. Market based dummy is a variable that takes 1 if the financial system is classified as market-based and 0 if it is bank-based. Developed financial systems are countries with above average stock market liquidity and the ratio of bank credit to private sector to GDP.

\begin{tabular}{|l|l|c|c|c|}
\hline $\begin{array}{l}\text { Performance } \\
\text { Measures }\end{array}$ & $\begin{array}{l}\text { Overall } \\
\text { Financial } \\
\text { Development }\end{array}$ & Bank-Based & Market-Based & T-test \\
\hline \hline \multirow{2}{*}{$\begin{array}{l}\text { Growth in Value } \\
\text { Added }\end{array}$} & Developed & 0.008 & 0.037 & $-4.93^{\mathbf{a}}$ \\
& Underdeveloped & 0.063 & 0.005 & $4.12^{\mathbf{a}}$ \\
\cline { 2 - 5 } & T- Test & $-5.87^{\mathbf{a}}$ & $2.69^{\mathbf{a}}$ & \\
\hline Growth in Production & Developed & -0.0004 & 0.0008 & $-2.72^{\mathbf{a}}$ \\
& Underdeveloped & 0.0017 & -0.0008 & $1.66^{\mathbf{c}}$ \\
\cline { 2 - 5 } & T-Test & $-2.14^{\mathbf{b}}$ & 1.40 & $-2.22^{\mathbf{b}}$ \\
\hline Growth in Economic & Developed & 0.0003 & 0.014 & 0.91 \\
\hline Efficiency & Underdeveloped & -0.00004 & -0.0019 & $-1.91^{\mathbf{c}}$ \\
\cline { 2 - 5 } & T-Test & 0.25 & $2.26^{\mathbf{b}}$ & 0.14 \\
\hline Growth in \\
Productivity & Developed & 0.013 & 0.022 & \\
\cline { 2 - 5 } & Underdeveloped & 0.014 & 0.012 & 0.90 \\
\cline { 2 - 5 } & T-Test & -0.16 & & \\
& & & & \\
\hline
\end{tabular}

${ }^{a}$ Significant at $1 \% ;{ }^{\mathrm{b}}$ Significant at $5 \% ;{ }^{\mathrm{c}}$ Significant at $10 \%$ 
Table 4: Financial Architecture, Financial Development and Economic Performance

The dependent variable is average annual growth in real value added. The parameter estimates are maximum likelihood estimates of regression equations containing random country and industry effects. The OLS equations do not contain random effects. ARCHITECTURE is a continuous variable that measures the degree of market orientation of a financial system and is a means-removed average of the size, activity, efficiency dimensions of financial architecture. MARKET is a dummy variable that takes 1 if the financial system is classified as market-based and 0 if it is bank-based. UNDER is an indicator variable that takes 1 for countries classified as financially underdeveloped and 0 otherwise. Stock market turnover is total value of shares traded divided by market capitalization. Bank credit ratio is claims of deposit money banks against the private sector divided by GDP. All regressions also contain log of initial per capita income and industry share in manufacturing (not reported). Industry Share in Manufacturing is calculated by dividing the real output of the industry in the country by the total real output of the manufacturing sector of the country. Coefficients of the country and industry effects are not reported. Asymptotic standard errors are given in parenthesis.

\begin{tabular}{|c|c|c|c|c|c|c|c|c|}
\hline & \multicolumn{4}{|c|}{ OLS } & \multicolumn{4}{|c|}{ Random Effects } \\
\hline & I & II & III & IV & I & II & III & IV \\
\hline Intercept & $\begin{array}{l}0.162^{\mathrm{a}} \\
(0.044)\end{array}$ & $\begin{array}{l}0.174^{\mathrm{a}} \\
(0.043)\end{array}$ & $\begin{array}{l}0.111^{\mathrm{b}} \\
(0.044)\end{array}$ & $\begin{array}{l}0.140^{\mathrm{a}} \\
(0.043)\end{array}$ & $\begin{array}{l}0.164^{\mathrm{b}} \\
(0.086)\end{array}$ & $\begin{array}{l}0.175^{\mathrm{b}} \\
(0.084)\end{array}$ & $\begin{array}{c}0.124 \\
(0.085)\end{array}$ & $\begin{array}{l}0.150^{\mathrm{c}} \\
(0.084)\end{array}$ \\
\hline Under & $\begin{array}{c}0.011 \\
(0.016)\end{array}$ & $\begin{array}{l}-0.015 \\
(0.012)\end{array}$ & $\begin{array}{l}0.049^{\mathrm{a}} \\
(0.017)\end{array}$ & $\begin{array}{c}0.011 \\
(0.014)\end{array}$ & $\begin{array}{c}0.013 \\
(0.031)\end{array}$ & $\begin{array}{l}-0.011 \\
(0.025)\end{array}$ & $\begin{array}{c}0.043 \\
(0.033)\end{array}$ & $\begin{array}{c}0.008 \\
(0.028)\end{array}$ \\
\hline Market & $\begin{array}{l}0.022^{\mathrm{c}} \\
(0.010)\end{array}$ & & $\begin{array}{l}0.024^{\mathrm{b}} \\
(0.010)\end{array}$ & & $\begin{array}{c}0.026 \\
(0.020)\end{array}$ & & $\begin{array}{c}0.027 \\
(0.019)\end{array}$ & \\
\hline Architecture & & $\begin{array}{l}0.017^{\mathrm{a}} \\
(0.005)\end{array}$ & & $\begin{array}{l}0.014^{\mathrm{a}} \\
(0.005)\end{array}$ & & $\begin{array}{l}0.018^{\mathrm{c}} \\
(0.011)\end{array}$ & & $\begin{array}{c}0.016 \\
(0.011)\end{array}$ \\
\hline Market X Under & $\begin{array}{l}-0.065^{a} \\
(0.016)\end{array}$ & & $\begin{array}{l}-0.073^{a} \\
(0.016)\end{array}$ & & $\begin{array}{l}-\mathbf{C . 0 6 6}^{\mathrm{b}} \\
(\mathbf{0 . 0 3 3})\end{array}$ & & $\begin{array}{l}-0.072^{b} \\
(0.031)\end{array}$ & \\
\hline $\begin{array}{l}\text { Architecture X } \\
\text { Under }\end{array}$ & & $\begin{array}{l}-0.046^{a} \\
(0.013)\end{array}$ & & $\begin{array}{l}-0.047^{a} \\
(0.018)\end{array}$ & & $\begin{array}{l}-0.044^{\mathrm{c}} \\
(0.026)\end{array}$ & & $\begin{array}{l}-0.044^{\circ} \\
(0.025)\end{array}$ \\
\hline Turnover & & & $\begin{array}{c}0.028 \\
(0.020)\end{array}$ & $\begin{array}{c}0.031 \\
(0.021)\end{array}$ & & & $\begin{array}{c}0.019 \\
(0.034)\end{array}$ & $\begin{array}{c}0.020 \\
(0.037)\end{array}$ \\
\hline Bank Ratio & & & $\begin{array}{l}0.094^{\mathrm{a}} \\
(0.024)\end{array}$ & $\begin{array}{l}0.076^{\mathrm{a}} \\
(0.023)\end{array}$ & & & $\begin{array}{l}0.074^{\mathrm{c}} \\
(0.044)\end{array}$ & $\begin{array}{c}0.056 \\
(0.045)\end{array}$ \\
\hline Per Capita GDP & $\begin{array}{l}-0.016^{\mathrm{a}} \\
(0.004)\end{array}$ & $\begin{array}{l}-0.017^{\mathrm{a}} \\
(0.004)\end{array}$ & $\begin{array}{l}-0.018^{\mathrm{a}} \\
(0.004)\end{array}$ & $\begin{array}{l}-0.019^{\mathrm{a}} \\
(0.004)\end{array}$ & $\begin{array}{l}-0.017^{\mathrm{b}} \\
(0.017)\end{array}$ & $\begin{array}{l}-0.017^{\mathrm{b}} \\
(0.009)\end{array}$ & $\begin{array}{l}-0.018^{b} \\
(0.008)\end{array}$ & $\begin{array}{l}-0.019^{b} \\
(0.009)\end{array}$ \\
\hline $\begin{array}{l}\text { Industry Share in } \\
\text { Manufacturing }\end{array}$ & $\begin{array}{c}0.035 \\
(0.089)\end{array}$ & $\begin{array}{c}0.043 \\
(0.089)\end{array}$ & $\begin{array}{c}0.050 \\
(0.086)\end{array}$ & $\begin{array}{c}0.053 \\
(0.087)\end{array}$ & $\begin{array}{c}0.060 \\
(0.072)\end{array}$ & $\begin{array}{c}0.060 \\
(0.072)\end{array}$ & $\begin{array}{c}0.060 \\
(0.073)\end{array}$ & $\begin{array}{c}0.060 \\
(0.073)\end{array}$ \\
\hline
\end{tabular}




\section{Table 5: Financial Architecture, Firm Size and Economic Performance}

Industry growth rate in value added is average annual growth rate over 1980 through 1995. Productivity and efficiency are computed based on parameter estimates of crosscountry stochastic production and cost frontiers on the panel of industry production and cost data. Production efficiency measures the degree to which an industry diverges from the efficient production frontier. Economic efficiency measures the degree to which an industry diverges from the best practice cost frontier. Architecture is a continuous variable that measures the degree of market orientation of a financial system and is a means-removed average of the size, activity, efficiency dimensions of financial architecture. Firm size is total real output of the manufacturing sector of the country divided by the number of firms in the manufacturing sector.

\begin{tabular}{|l|l|c|c|c|}
\hline $\begin{array}{l}\text { Performance } \\
\text { Measures }\end{array}$ & $\begin{array}{l}\text { Country Ranking } \\
\text { Based on Size of } \\
\text { Average } \\
\text { Manufacturing Firm }\end{array}$ & Bank -Based & $\begin{array}{c}\text { Market- } \\
\text { Based }\end{array}$ & T-test \\
\hline \hline \multirow{2}{*}{$\begin{array}{l}\text { Growth in Value } \\
\text { Added }\end{array}$} & Bottom 25\% & 0.065 & -0.046 & $4.41^{\mathbf{a}}$ \\
& Top 25\% & 0.008 & 0.030 & $-2.19^{\mathbf{b}}$ \\
\cline { 2 - 5 } $\begin{array}{l}\text { Growth in Production } \\
\text { Efficiency }\end{array}$ & Bottom 25\% & $5.42^{\mathbf{a}}$ & $-3.05^{\mathbf{a}}$ & \\
\hline & Top 25\% & 0.003 & -0.003 & $2.15^{\mathbf{b}}$ \\
\cline { 2 - 5 } & T-Test & -0.0003 & 0.0005 & -1.14 \\
\hline $\begin{array}{l}\text { Growth in Economic } \\
\text { Efficiency }\end{array}$ & Bottom 25\% & $2.58^{\mathbf{b}}$ & -1.42 & \\
\cline { 2 - 5 } & Top 25\% & 0.002 & -0.005 & $2.01^{\mathbf{b}}$ \\
\cline { 2 - 5 } & T-Test & 1.27 & $-1.94^{\mathbf{c}}$ & 0.10 \\
\hline $\begin{array}{l}\text { Growth in } \\
\text { Productivity }\end{array}$ & Bottom 25\% & 0.022 & -0.0005 & 0.93 \\
& Top 25\% & 0.015 & 0.020 & -0.54 \\
\cline { 2 - 5 } & T-Test & 0.74 & -0.85 & \\
\hline
\end{tabular}

${ }^{a}$ Significant at $1 \% ;{ }^{b}$ Significant at $5 \% ;{ }^{c}$ Significant at $10 \%$ 


\section{Table 6: Financial Architecture, Firm Size, and Economic Performance}

The dependent variable is average annual growth in value added over 1980-1995. The parameter estimates are maximum likelihood estimates of regression equations containing random country and industry effects. The OLS equations do not contain random effects. ARCHITECTURE is a continuous variable that measures the degree of market orientation of a financial system and is a means-removed average of the size, activity, efficiency dimensions of financial architecture. MARKET is a dummy variable that takes 1 if the financial system is classified as market-based and 0 if it is bank-based. UNDER is an indicator variable that takes 1 for countries classified as financially underdeveloped and 0 otherwise. SIZE is an indicator variable that takes 1 for countries with smaller average manufacturing firm size and 0 otherwise. Stock market turnover is total value of shares traded divided by market capitalization. Bank credit ratio is claims of deposit money banks against the private sector divided by GDP. All regressions also contain log of initial per capita income and industry share in manufacturing (not reported). Industry Share in Manufacturing is calculated by dividing the real output of the industry in the country by the total real output of the manufacturing sector of the country. Coefficients of the country and industry effects are not reported. Asymptotic standard errors are given in parenthesis.

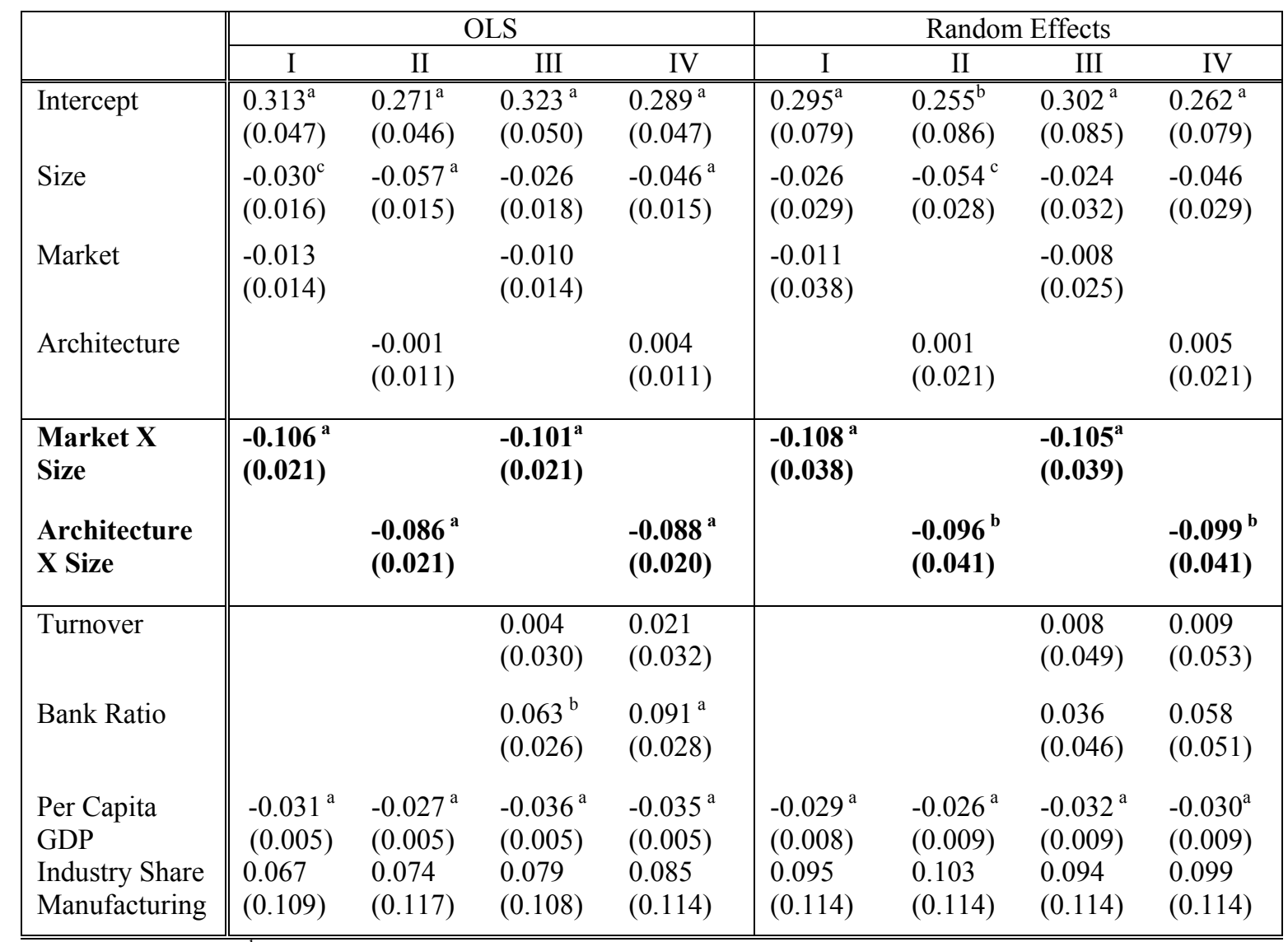

a Significant at $1 \% ;{ }^{b}$ Significant at $5 \% ;{ }^{c}$ Significant at $10 \%$ 


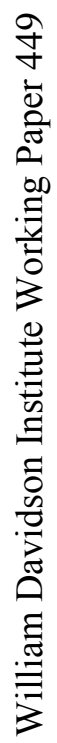

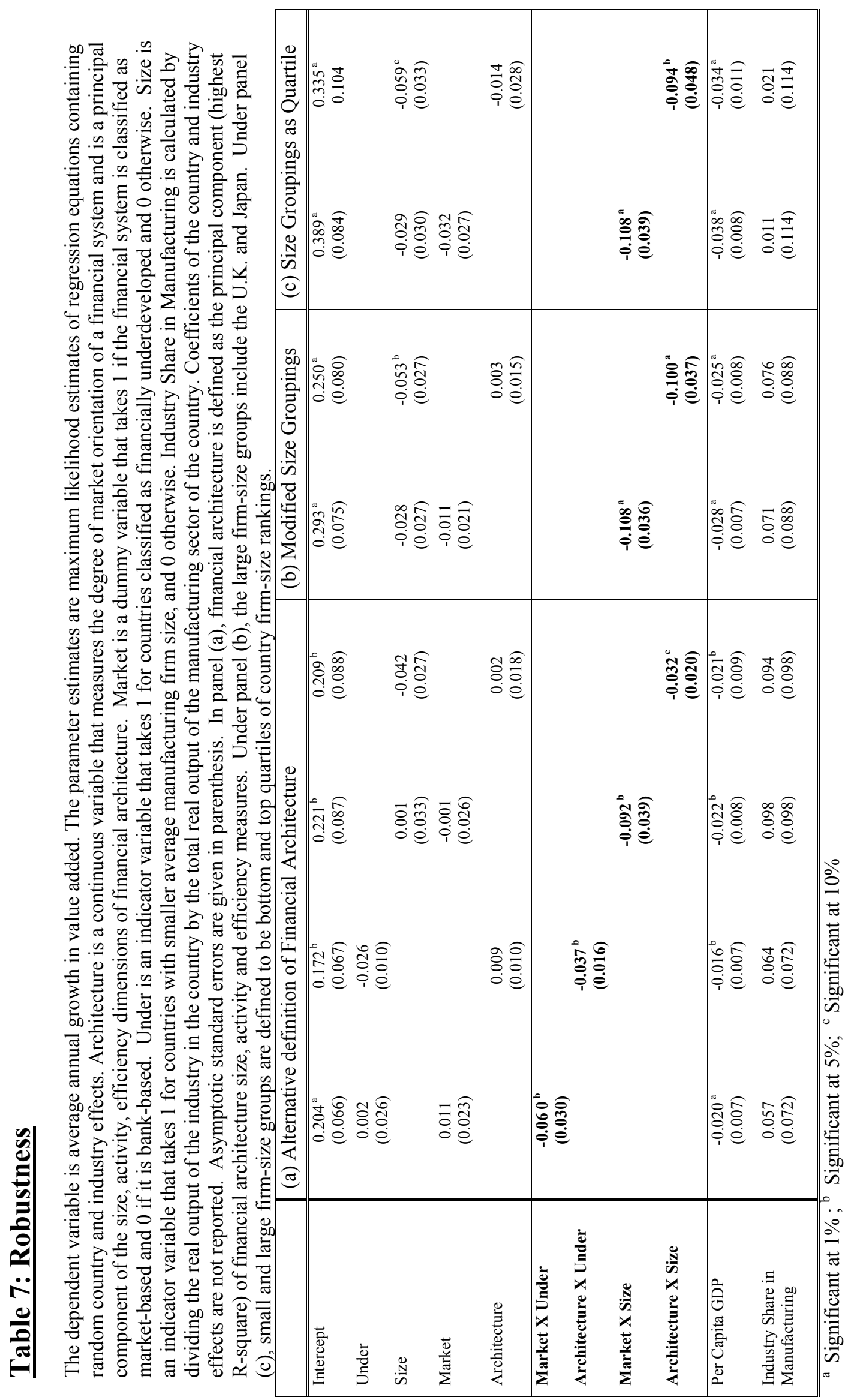




\section{Appendix I: Summary Statistics}

UNDER is an indicator variable that takes 1 for countries classified as financially underdeveloped and 0 otherwise. MARKET is a dummy variable that takes 1 if the financial system is classified as market-based and 0 if it is bank-based. ARCHITECTURE is a continuous variable that measures the degree of market orientation of a financial system and is a means-removed average of the size, activity, efficiency dimensions of financial architecture. Average Firm size is calculated as total real output of the manufacturing sector of the country divided by the number of firms in the manufacturing sector. SIZE is an indicator variable that takes 1 for countries with smaller average manufacturing firm size and 0 otherwise. Stock market turnover is total value of shares traded divided by market capitalization. Bank credit ratio is claims of deposit money banks against the private sector divided by GDP. Industry Share in Manufacturing is calculated by dividing the real output of the industry in the country by the total real output of the manufacturing sector of the country. Industry growth rate in value added is average annual growth rate over 1980 through 1995.

\begin{tabular}{|l||ccccc|}
\hline Variables & $\mathrm{N}$ & Mean & Std. Dev. & Minimum & Maximum \\
\hline \hline UNDER & 281 & 0.352 & 0.479 & 0 & 1 \\
MARKET & 281 & 0.399 & 0.490 & 0 & 1 \\
ARCHITECTURE & 281 & 0.059 & 0.654 & -0.820 & 1.960 \\
$\begin{array}{l}\text { Log of Average Firm } \\
\text { Size }\end{array}$ & 281 & 10.806 & 0.883 & 7.680 & 12.352 \\
$\begin{array}{l}\text { SIZE } \\
\text { Stock Market Turnover }\end{array}$ & 206 & 0.252 & 0.435 & 0 & 1 \\
$\begin{array}{l}\text { Ratio } \\
\text { Bank Ratio }\end{array}$ & 280 & 0.270 & 0.197 & 0.010 & 0.897 \\
$\begin{array}{l}\text { Log Per Capita GDP } \\
\text { Share of Industry's }\end{array}$ & 281 & 8.833 & 1.355 & 5.780 & 10.179 \\
$\begin{array}{l}\text { Value Added to Total } \\
\text { Manufacturing }\end{array}$ & 280 & 0.053 & 0.047 & 0.004 & 0.238 \\
\hline $\begin{array}{l}\text { Growth in Real Value } \\
\text { Added }\end{array}$ & 251 & 0.020 & 0.047 & -0.268 & 0.200 \\
\hline \hline
\end{tabular}




\section{DAVIDSON INSTITUTE WORKING PAPER SERIES - Most Recent Papers}

The entire Working Paper Series may be downloaded free of charge at: www.wdi.bus.umich.edu

CURRENT AS OF 3/28/02

\begin{tabular}{|c|c|c|}
\hline Publication & Authors & Date \\
\hline $\begin{array}{l}\text { No. 449: Financial Architecture and Economic Performance: } \\
\text { International Evidence }\end{array}$ & Solomon Tadesse & Aug. 2001 \\
\hline $\begin{array}{l}\text { No. 448: Growth Slowdown Under Central Planning: A Model of Poor } \\
\text { Incentives }\end{array}$ & Zuzana Brixiová and Aleš Bulí̌ & Mar. 2002 \\
\hline $\begin{array}{l}\text { No. 447: Disentangling Treatment Effects of Polish Active Labor } \\
\text { Market Policies: Evidence from Matched Samples }\end{array}$ & $\begin{array}{l}\text { Jochen Kluve, Hartmut Lehmann, } \\
\text { and Christoph M. Schmidt }\end{array}$ & Jan. 2002 \\
\hline $\begin{array}{l}\text { No. 446: The Impact of Socialist Imprinting and Search for Knowledge } \\
\text { on Resource Change: An Empirical Study of Firms in Lithuania }\end{array}$ & $\begin{array}{l}\text { Aldas Kriauciunas and Prashant } \\
\text { Kale }\end{array}$ & Mar. 2002 \\
\hline $\begin{array}{l}\text { No. 445: The Costs, Wealth Effects, and Determinants of International } \\
\text { Capital Raising: Evidence from Public Yankee Bonds }\end{array}$ & $\begin{array}{l}\text { Darius P. Miller and John J. } \\
\text { Puthenpurackal }\end{array}$ & Oct. 2001 \\
\hline No. 444: Financial Institutions, Contagious Risks, and Financial Crises & $\begin{array}{l}\text { Haizhou Huang and Chenggang } \\
\mathrm{Xu}\end{array}$ & Nov. 2001 \\
\hline No. 443: Banks as Catalysts for Industrialization & $\begin{array}{l}\text { Marco Da Rin and Thomas } \\
\text { Hellmann }\end{array}$ & Oct. 2001 \\
\hline $\begin{array}{l}\text { No. 442: Bank-Based or Market-Based Financial Systems: Which is } \\
\text { Better? }\end{array}$ & Ross Levine & Feb. 2002 \\
\hline $\begin{array}{l}\text { No. 441: Migration and Regional Adjustment and Asymmetric Shocks } \\
\text { in Transition Economies }\end{array}$ & Jan F & Feb. 2002 \\
\hline $\begin{array}{l}\text { No. 440: Employment and Wages in Enterprises Under Communism } \\
\text { and in Transition: Evidence From Central Europe and Russia }\end{array}$ & $\begin{array}{l}\text { Swati Basu, Saul Estrin, and Jan } \\
\text { Svejnar }\end{array}$ & June 2000 \\
\hline No. 439: Small business in Russia: A Case Study of St. Petersburg & Alessandro Kihlgren & Jan. 2002 \\
\hline $\begin{array}{l}\text { No. 438: Foreign Direct Investment as Technology Transferred: } \\
\text { Some Panel Evidence from the Transition Economies }\end{array}$ & $\begin{array}{l}\text { Nauro F. Campos and Yuko } \\
\text { Kinoshita }\end{array}$ & Jan. 2002 \\
\hline No. 437: Whistleblowing, MNC's and Peace & Terry Morehead Dworkin & Feb. 2002 \\
\hline $\begin{array}{l}\text { No. 436: A Note on Measuring the Unofficial Economy in the Former } \\
\text { Soviet Republics }\end{array}$ & $\begin{array}{l}\text { Michael Alexeev and William } \\
\text { Pyle }\end{array}$ & Sept. 2001 \\
\hline $\begin{array}{l}\text { No. 435: The Ownership School vs. the Management School of State } \\
\text { Enterprise Reform: Evidence from China }\end{array}$ & David D. Li and Changqi Wu & Jan. 2002 \\
\hline $\begin{array}{l}\text { No. 434: The Effect of Ownership and Competitive Pressure on Firm } \\
\text { Performance in Transition Countries: Micro Evidence from Bulgaria, } \\
\text { Romania and Poland. }\end{array}$ & $\begin{array}{l}\text { Manuela Angelucci, Saul Estrin, } \\
\text { Jozef Konings, and Zbigniew } \\
\text { Zolkiewski }\end{array}$ & Jan. 2002 \\
\hline No. 433: The End of Moderate Inflation in Three Transition Economies? & Josef C. Brada and Ali M. Kutan & Jan. 2002 \\
\hline $\begin{array}{l}\text { No. 432: What Drives the Speed of Job Reallocation During Episodes of } \\
\text { Massive Adjustment? }\end{array}$ & $\begin{array}{l}\text { Stepan Jurajda and Katherine } \\
\text { Terrell }\end{array}$ & Jan. 2002 \\
\hline $\begin{array}{l}\text { No. } 431 \text { Forthcoming in: The Journal of Economic Perspectives, } \\
\text { "Competition and Corporate Governance in Transition," 16(2) Feb. } \\
2002 .\end{array}$ & Saul Estrin & Dec. 2001 \\
\hline $\begin{array}{l}\text { No. 430: Corporate Governance in the Cause of Peace: An } \\
\text { Environmental Perspective }\end{array}$ & Don Mayer & Jan. 2002 \\
\hline No. 429: Why do Governments Privatize? & $\begin{array}{l}\text { Loren Brandt, Hongbin Li, and } \\
\text { Joanne Roberts }\end{array}$ & Dec. 2001 \\
\hline No. 428: Testing Russia's Virtual Economy & Vlad Ivanenko & Dec. 2001 \\
\hline No. 427: War and the Business Corporation & Eric W. Orts & Dec. 2001 \\
\hline $\begin{array}{l}\text { No. 426: Partial Privatization and Firm Performance: Evidence from } \\
\text { India }\end{array}$ & Nandini Gupta & Dec. 2001 \\
\hline $\begin{array}{l}\text { No. 425: Direct Foreign Investments and Productivity Growth in } \\
\text { Hungarian Firms, 1992-1999 }\end{array}$ & Jérôme Sgard & Nov. 2001 \\
\hline $\begin{array}{l}\text { No. 424: Banking Passivity and Regulatory Failure in Emerging } \\
\text { Markets: Theory and Evidence from the Czech republic. }\end{array}$ & Jan Hanousek and Gerard Roland & July 2001 \\
\hline
\end{tabular}

